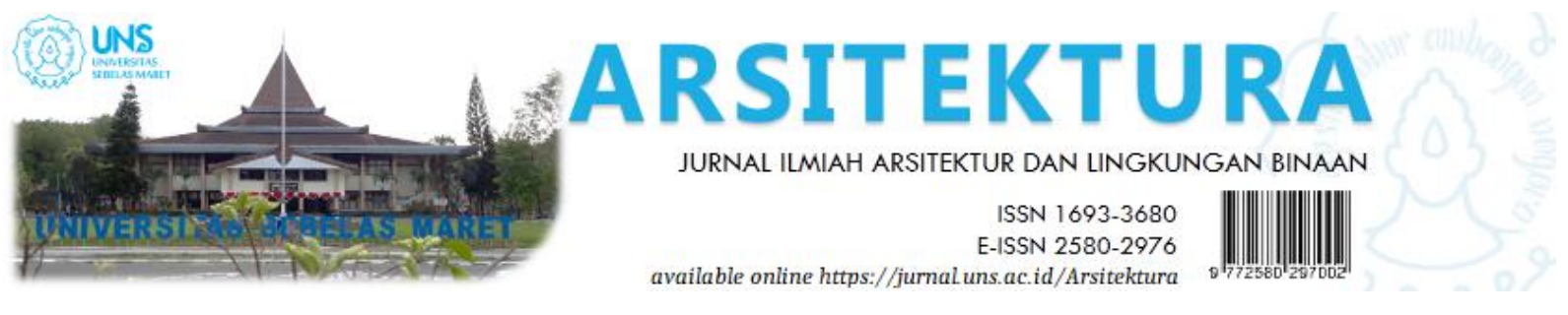

Volume 19 Issue 1 April 2021, pages:01-12

\title{
Ketersediaan dan Pemanfaatan Ruang Terbuka Hijau di Kampus UKDC Surabaya
}

\section{Availability and Utilization of Green Open Space at UKDC Surabaya Campus}

\author{
Heristama Anugerah Putra ${ }^{1 *}$, Josephine Roosandriantini ${ }^{2}$ \\ Architecture Department, Technic Faculty, Dama Cendika Catholic University ${ }^{1 *}$ \\ heristama.putra@ukdc.ac.id \\ Architecture Department, Technic Fa culty, Dama Cendika Catholic University ${ }^{2}$
}

DOI: https://doi.org/10.20961/arst.v19i1.44374

Received: September 15,2020 Revised: November 16,2020 Accepted: January 5,2021 Available online: April 30,2021

\begin{abstract}
Increasing temperatures and changes in global weather are currently affecting all countries, including Indonesia. This problem is what we can call global warming. The city of Surabaya in particular experiences this problem where there is a shift in time related to the dry season and the rainy season. The formation of green open spaces is important in a city to reduce the impact that is imposed globally. The main target expected is to take part in reducing the temperature in the city of Surabay a so that the ecologicalbalance in it is maintained even though it is small or limited to existing sites. This is based on regional regulations regarding the proportion of green open space that must be presented according to data from Bappeko Surabaya. The method in research using literature studies, observational studies, and study designs in a form tailored to the analysis. The result of this research is to add the availability and utilization of green open space in the form of vertical vegetation in the UKDC campus building to provide additional green open space for both the UKDC campus and the city of Surabaya. So in other words, the new UKDC campus building can provide additional green open space to achieve the availability of green open space on private land.
\end{abstract}

Keywords: Globalwarming, Campus Forest, Green Open Space, Vegetation, Building envelope

\section{PENDAHULUAN}

Pembangunan dan perkembangan kota Surabaya dewasa ini semakin pesat sehingga membawa konsekuensi pada pemenuhan ruang terbuka hijau semakin terbatas. Selain itu juga pertumbuhan penduduk yang dari tahun ke tahun semakin meningkat, sehingga semakin menyebabkan masalah baru yaitu kota mengalami kurangnya lahan yang luas.
Permasalahan di dunia tidak hanya berhenti pada perkembangan kota yang semakin berkembang di bidang industri, pendidikan, tetapi juga dampak dari perkembangan tersebut yaitu terjadinya global warming. Kondisi global warming ini menyebabkan kondisi lingkungan semakin buruk. Permasalahan global warming dapat memicu ketidakpastian cuaca dan perubahan iklim yang terus-menerus 
berubah. Jika permasalahan ini tidak diperhatikan maka akan berakibat fatal pada tingkat polusi dan kesehatan sebuah kota terhadap penduduk. Sebab, secara tidak langsung kondisi lingkungan yang buruk dapat mempengaruhi pola tingkah laku manusia.

Permasalahan yang disebabkan karena global warming jika tidak diperhatikan maka akan berdampak pada kerusakan lingkungan. Salah satu cara mengatasi pengurangan pemanasan global ini dapat dengan menerapkan konsep Ruang Terbuka Hijau di area kampus. Hal itu serupa dengan yang disebutkan dalam The International Alliance of Research Universities (2007), dimana konsep Go Green Campus ini lebih mengedepankan penyediaan dan pemanfaatan ruang terbuka hijau (Suciyani, 2018).

Pemerintah bersama masyarakat harus ikut andil dalam mengurangi ataupun mengatasi permasalahan ini. Perencanaan pembentukan Ruang Terbuka Hijau (RTH) merupakan salah satu cara untuk dapat tetap menjaga keseimbangan, keserasian, dan keselamatan antara fungsi ekologis dan sosial antara gedung dan lingkungan sekitar. Permasalahan lingkungan dengan kurangnya Ruang Terbuka Hijau (RTH), dalam mengedepankan penyediaan dan pemanfaatan RTH di lingkungan kampus. Penyediaan RTH tersebut juga dapat digunakan oleh mahasiswa dalam melakukan aktivitas sosial maupun dapat menjadi sarana belajar di luar kelas (Suciyani, 2018).

Arsitektur dalam hal ini bangunan juga dapat dikatakan sebagai salah satu penyumbang terjadinya global warming. Mulai dari material bangunan yang digunakan sampai besaran energi yang dibutuhkan dalam sebuah gedung. Hal ini seharusnya menjadi perhatian bagi para arsitek dalam merancang sebuah bangunan, dimana kedepannya bangunan harus hemat energi dan sustainable.

Secara teoritis jika berbicara mengenai Ruang Terbuka Hijau (RTH) berkaitan dengan sebidang lahan yang memiliki kenyamanan, keamanan dan keindahan bagi penggunanya dan memiliki fungsi yang beranekaragam (Suciyani, 2018). Selain itu RTH dalam UU RI No. 26 Tahun 2007 dapat dikatakan sebagai sebuah wadah untuk dapat melakukan aktivitas manusia baik secara individu ataupun kelompok. Selain itu Ruang Terbuka Hijau (RTH) umumnya berupa ruang terbuka yang didalamnya terdapat berbagai macam vegetasi dalam bentuk sebuah kawasan / wilayah yang memiliki berbagai fungsi sebagai area rekreasi, sosial, estetika, fisik kota, dan ekologis (Dewiyanti, 2009). Ruang terbuka hijau (RTH) memiliki manfaat secara ekologis yaitu untuk mengurangi polusi udara dan memperbaiki sistem tata air kota (Kosaming, 2006), RTH juga dapat melindungi masalah lingkungan dengan menurunkan suhu, lebih sejuk, mengikat $\mathrm{O}_{2}$, dan membantu mengeluarkan gas oksigen. Vegetasi dan sebuah Ruang Terbuka Hijau (RTH) selain berfungsi sebagai estetika juga berfungsi sebagai penyeimbang ekologi dalam sebuah wilayah atau daerah. Kehadiran dan penambahan jumlah RTH secara fungsi utamanya dapat menurunkan suhu dan iklim sebuah kota akibat dari proses fotosintesis tumbuhan. Tumbuhan dan vegetasi sangat diperlukan dalam tiap titik di perkotaan mengingat tumbuhan mampu menjaring $\mathrm{CO}_{2}$ dan melepaskan $\mathrm{O}_{2}$ kembali ke udara melalui proses fotosintesis dengan bantuan sinar matahari.

Ruang terbuka hijau juga dapat dikatakan sebagai taman kota yang mampu memberikan wadah rekreasi dan komunikasi bagi warga kota (Caesarina, 2019). Ruang Terbuka Hijau diperhatikan dikarenakan keinginan menciptakan kenyamanan, kesejukan dan meningkatkan kualitas lingkungan, sehingga perlu dipahami bahwa ruang terbuka hijau (RTH) adalah merupakan sebuah lahan luas yang berupa sebuah tanaman di sepanjang jalan, gerombol di beberapa sudut di sebuah lokasi/bangunan seperti taman, hutan kampus (Nugradi, 2009). Peningkatan kualitas lingkungan dapat diimplementasikan dalam sebuah ruang pergerakan linier dan tiap koridor antar ruang, ruang terbuka hijau juga dapat diterapkan di beberapa ruang tersebut. Ruang terbuka hijau terbagi menjadi tiga kelompok yaitu taman, lanskap dan vegetasi (berupa kumpulan pohon berupa hutan) (Chafid Fandeli, Kaharuddin, Mukhlison, 2004: 133). Selain itu menurut Arifin dan Nurhayati (2000) dikatakan bahwa RTH merupakan sebidang lahan terbuka yang ditata dan memiliki keindahan, kenyamanan dan keamanan bagi 
pemilik atau pengguna di lingkungan tersebut. RTH tersebut juga harus memiliki nilai estetika dan berfungsi sebagai ruang terbuka dan fungsinya yang beraneka ragam. Seperti pada tujuan dari penelitian ini bahwa peneliti ingin mengkaji ketersediaan dan pemanfaatan RTH di kampus UKDC. Ruang terbuka hijau (RTH) dapat dibagikan beberapa kategori, yaitu berdasarkan kealamiannya, berdasarkan sifat dan karakter ekologis, berdasarkan penggunaan lahan atau kawasan fungsionalnya, berdasarkan status kepemilikannya. Kategori tersebut dapat dijelaskan sebagai berikut : (Nugradi,2009)

a. Berdasarkan kealamiannya

Ruang terbuka hijau yang termasuk kategori berdasarkan kealamiannya, yaitu terbagi menjadi dua yaitu RTH alamiah dan RTH non alamiah

b. Berdasarkan sifat dan karakter ekologis Ruang terbuka hijau yang termasuk kategori berdasarkan ekologis dan karakter, yaitu terbagi menjadi dua yaitu RTH jalur dan RTH kawasan

c. Berdasarkan penggunaan lahan atau kawasan fungsional

Ruang terbuka hijau yang termasuk dalam kategori berdasarkan kawasan fungsional dapat sebagai taman, jalur hijau

d. Berdasarkan status kepemilikan

Ruang terbuka hijau yang termasuk dalam kategori ini lahan privat dan non privat tergantung kepemilikannya, termasuk milik pemerintah atau swasta.

Menurut Direktorat Jenderal Penataan Ruang Departemen Pekerjaan Umum (2008) tertuang beberapa fungsi dibangunnya ruang terbuka hijau yakni:

a. Fungsi bioekologis

Ruang terbuka hijau memiliki fungsi sebagai pengatur sistem lingkungan mulai dari mengelola sistem udara, resapan air dan sebagai peneduh

b. Fungsi sosial ekonomi

Ruang terbuka hijau memiliki fungsi sebagai objek wisata dan rekreasi warga kota

c. Ekosistem perkotaan

Ruang terbuka hijau memiliki fungsi sebagai wadah untuk timbal balik antara makhluk hidup dengan lingkungannya

d. Estetika
Ruang terbuka hijau memiliki fungsi sebagai visual dan bentuk dari sebuah bangunan (building envelope).

Berdasarkan pendapat dari para ahli mengenai RTH terlihat bahwa keberadaan atau peran RTH sangatlah penting di daerah perkotaan. Secara spesifik peran RTH di kampus UKDC bagi pihak internal mampu menjadi barier atau building envelope yang memberikan tingkat kenyamanan bagi pengguna di dalamnya terhadap bising dan panas matahari, sedangkan bagi pihak eksternal RTH yang sudah terpenuhi dapat menjadi estetika dari sebuah kota dan bangunan dapat secara langsung berkomunikasi dengan lingkungannya. Saat ini peranan kampus UKDC dalam pemenuhan RTH terhadap kota Surabaya dapat dikatakan minim dikarenakan site yang dimiliki tidak terlalu luas. Karena kondisi site yang tidak terlalu luas ini dan hampir $90 \%$ adalah area terbangun dan dengan perkerasan (jalan paving) sehingga sangat diharapkan untuk mewujudkan area RTH dilahan kampus UKDC. Dengan menghadirkan dan menambahkan RTH yang luasan minimalnya sesuai dengan peraturan yang ada, dimana disesuaikan juga dengan luasan lahan, diharapkan dapat menyumbangkan produksi $\mathrm{O} 2$ khususnya bagi lingkungan disekitar kampus UKDC. Selain itu dapat pula menciptakan daerah ekologi baru. Di kota Surabaya, telah diadakan pengadaan RTH yang dari tahun ke tahun semakin bertambah dengan semakin banyak taman kota, dengan berbagai nama diantaranya taman pelangi, taman prestasi, taman kunang-kunang, dan masih banyak lainnya. Selain itu pihak pemerintah kota Surabaya menganjurkan warganya untuk memiliki dan menanam minimal satu pohon di lingkungan dan lahan tempat tinggalnya. Perencanaan RTH ini dimaksudkan untuk mengurangi dan menekan tingkat polusi di kota Surabaya yang dari tahun ke tahun juga meningkat. Polusi ini sendiri banyak diakibatkan oleh kendaraan bermotor, aktivitas perindustrian dan kebutuhan energi akan sebuah bangunan gedung ataupun rumah tinggal. 
Dalam suatu tata ruang sebuah kota elemen ruang terbuka hijau bisa dikategorikan sebagai salah satu jenis di dalam keanekaragaman hayati dalam bentuk vegetasi tanaman yang wujudnya RTH alami (kawasan lindung) dan RTH binaan (kawasan non-publik) (Kusmana, 2015). Ruang terbuka hijau juga memiliki peranan sebagai penyelaras lingkungan ekologi dan dapat membantu menyerap polusi udara. Dalam kenyataannya vegetasi menjadi sangat penting dalam pengoptimalisasi fungsi dari sebuah kota hijau. Luasan lahan yang dimiliki oleh kampus UKDC saat ini sebesar $6.922 \mathrm{~m} 2$ dan ketersediaan luas RTH eksisting sendiri masih kurang yakni $180,75 \mathrm{~m}^{2}$ atau berkisar $2,61 \%$ dari luasan site. Keberadaan RTH sangat diperlukan perannya dalam sebuah lahan terbangun sehingga luasan lahan tidak sebanding dengan area resapan air. Sehingga, lokasi penelitian ini akan dilakukan di lingkungan kampus UKDC. Penelitian ini diharapkan mampu untuk memenuhi peraturan pemerintah terkait pemenuhan RTH di site yang dimiliki. Selain itu dapat dikatakan sebagai kampus yang ramah lingkungan, walaupun secara visual gedung yang dimiliki oleh UKDC sangat minim sekali lahan terbuka hijau. Kampus UKDC ini juga memiliki bangunan baru yang difungsikan sebagai kelas kuliah, ruang dosen, dan unit kerja akademik lainnya. Kampus UKDC ini memiliki dua bagian gedung yaitu gedung lama dan gedung baru, di belakang bangunan yang lama difungsikan sebagai lahan parkir dan saat ini sedang dilakukan proses pembangunan asrama untuk mahasiswa UKDC yang dari luar Surabaya.

Semakin bertambahnya sarana dan prasarana dari kampus UKDC ini, dan juga bertambahnya pengguna/user yang beraktivitas di dalam gedung, maka hal yang penting dan perlu diperhatikan adalah kenyamanan, keindahan, keserasian, kesejukan dan kelestarian lingkungan sekitar pengguna maupun gedung itu sendiri. Dalam penelitian ini akan dibentuk RTH yang dihadirkan dalam bentuk hutan kampus secara vertikal. Pembentukan RTH secara horisontal saat ini sudah ada secara eksisting, dimana bentuknya hanya berupa pulau-pulau taman yang didalamnya banyak berisikan jenis-jenis tanaman dan pohon guna menghadirkan softscape dan area resapan lainnya. Sementara hutan kampus secara vertikal dengan cara menghadirkan vegetasi yang mengelilingi bangunan gedung baru kampus UKDC dapat berfungsi juga sebagai building envelope. Meskipun adanya vegetasi di sekeliling selimut gedung kampus UKDC ini juga harus memanfaatkan pencahayaan pasif secara maksimal untuk aktivitas dan kegiatan di dalam gedungnya. Hal ini didasarkan dari tingkat kenyamanan pengguna di dalam gedung terkait dengan pencahayaan pasif, sehingga pengguna dapat merasa nyaman beraktivitas di dalam gedung. Vegetasi yang dihadirkan dalam pemenuhan Ruang Terbuka Hijau (RTH) di kampus UKDC ini diharapkan tidak menutupi gedung secara keseluruhan tetapi beberapa bagian yang dapat menghasilkan kenyamanan pengguna.

Luasan dari tutupan atau besaran sebuah pohon mempengaruhi pula terhadap daya serap emisi $\mathrm{CO}_{2}$ di suatu lingkungan sehingga perlu pula pemilihan jenis-jenis tanaman yang tepat dalam penempatannya dan ini semua merupakan faktor akan ketersediaan ruang terbuka hijau di suatu kawasan (Kusumawardani, 2017). Meningkatnya volume kepadatan dan jenis kendaraan yang melakukan gerak mobilitas di suatu wilayah, khususnya di Jalan Dr. Ir. Soekarno yang menjadi site penelitian ini menjadikan tingkat emisi $\mathrm{CO}_{2}$ di sekitar kampus UKDC menjadi meningkat pula. Selain sebagai penjaga stabilitas kadar emisi $\mathrm{CO}_{2}$ ruang terbuka hijau harus mampu menjaga ekologi lingkungan, penahan estetika dan kelanjutan dari suatu kota (Putri D, 2012).

Pada lahan tertentu memiliki faktor dan fungsinya masing-masing dalam skala prioritas, dimana untuk lahan terbuka hijau diperlukan adanya ketersediaan pohon yang mampu menyerap kadar $\mathrm{CO}_{2}$ diudara (Prabowoningsih, 2018). Hal ini umumnya sudah tertuang di dalam perencanaan tata ruang sebuah kota. Penelitian ini bertujuan untuk mengkaji ketersediaan lahan ruang terbuka hijau di lingkungan kampus UKDC dan juga pemenuhan ruang terbuka hijau sebagai hutan kampus. Keberadaan ruang terbuka hijau ini dapat menjaga keseimbangan lingkungan binaan, sehingga dapat menjadi kampus yang ramah lingkungan. Ruang terbuka hijau sendiri dapat pula berfungsi sebagai penghasil iklim mikro, mengurangi polusi udara dan mengendalikan kelestarian di lingkungan kota. 


\section{METODE}

Metode penelitian yang digunakan dalam penelitian ini yaitu Data Scape (Jormakka, 2007). Tahap awal dilakukan pengumpulan data literatur dan studi observasi lapangan yang kemudian dilakukan analisa data guna mendapatkan sintesa. Untuk membantu mendapatkan hasil perancangan yang diinginkan metode yang digunakan tadi dimasukkan ke dalam alur proses desain. Dengan menggunakan Archer's Model of the design process, yaitu lebih ditekankan pada solusi yang dihasilkan untuk menjawab sebuah permasalahan RTH pada kampus UKDC guna memenuhi dan mendapatkan ketersediaan luasan RTH yang diharapkan. Untuk mendapatkan output desain dengan metode ini melalui beberapa tahap dan proses. Skema metode Archer's yang digunakan yaitu sebagai berikut:

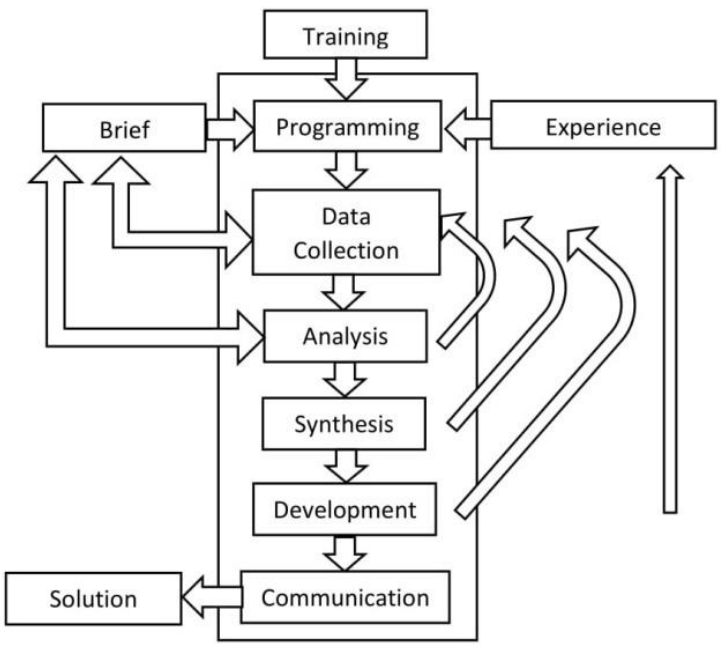

Gambar 1. Metode Archer's Design Process Sumber: Cross, 1994

Metode Data Scape dipakai pada tahap Analytical Phase di dalam Data Collection. Teknik analisa data yaitu menggunakan pengumpulan data yang akan digunakan dalam penelitian ini, data literatur berupa RTH di dalam perda kota Surabaya, dokumentasi di lapangan, lokasi site. Sintesa yang dilakukan dari hasil data yang diperoleh dapat digunakan untuk mengembangkan sebuah solusi sebelum dapat dikomunikasikan terlebih dahulu perlu dilakukan pengembangan desain untuk mendapatkan sebuah desain gedung kampus dengan kondisi eksisting yang ada menjadi sebuah gedung yang mampu memfasilitasi RTH di lingkungan kampus UKDC. Solusi yang ditawarkan dalam penelitian ini memberikan pemenuhan $\mathrm{O}_{2}$, menghadirkan vegetasi bagi skala mikro (site) dan makro (kota Surabaya) serta untuk menjaga keseimbangan lingkungan binaan.

\section{HASIL DAN PEMBAHASAN}

Ruang terbuka hijau memiliki banyak sekali fungsi dan perannya dalam sebuah kota ataupun wilayah. Terbentuknya ruang terbuka hijau di beberapa titik menjadi poin penting dalam investasi kota dalam hal keberlangsungan dan keberagaman lingkungan untuk jangka panjang. Ruang Terbuka Hijau atau disingkat RTH adalah suatu bentuk pemanfaatan lahan pada satu kawasan yang diperuntukkan untuk penghijauan tanaman. Sehingga dalam penelitian kali ini ruang terbuka hijau dapat dikategorikan menurut fungsi dan kegiatannya dalam bentuk taman/hutan kampus di lingkungan UKDC. Keberadaan RTH di suatu kotajuga memiliki fungsi sebagai pengatur pola hubungan ketersediaan kualitas suhu udara di lingkungan sekitar (Ahmad, 2012).

Menurut Peraturan Daerah Kota Surabaya No 12 Tahun 2014 menyatakan bahwa penyediaan ruang terbuka hijau di lahan atau gedung milik swasta, yang dalam hal ini adalah kampus UKDC maka harus memenuhi minimal $10 \%$ dari luas site yaitu sebesar $6.922 \mathrm{~m}^{2}$. Dalam peraturan terkait ketentuan umum peraturan zonasi, dimana bangunan vertikal dengan intensitas rendah sampai menengah harus menyediakan pemanfaatan ruang untuk pemenuhan RTH. Dari hasil pengukuran site dan pengembangan kampus UKDC ke depannya serta melihat site plan yang ada (lihat Gambar 2). Ketersediaan dan pemanfaatan RTH pada kampus UKDC lebih diarahkan secara vertikal karena dengan kondisi lahan yang terbatas sudah tidak memungkinkan pembentukan dan penyediaan RTH secara horisontal, maka pembentukan RTH lebih diarahkan secara vertikal. Banyak lahan-lahan RTH khususnya di kota besar area resapan air mengalami perubahan fungsi lahan menjadi area pembangunan akan kebutuhan aktivitas penduduk (Dwiyanto, 2009) 
Ruang terbuka hijau secara vertikal ini diwujudkan dalam rupa berbagai vegetasi tanaman baik dalam pot, tanaman rambat ataupun berbagai jenis tanaman lainnya. Lokasi kampus UKDC yang langsung berhadapan dengan jalan utama dengan volume lalu lalang kendaraan yang tinggi diharapkan vegetasi yang dihadirkan mampu membantu menyerap karbon dioksida dan monoksida. Bila ada angin panas yang bergerak ke arah gedung kampus UKDC dengan vegetasi vertikal yang sudah terpenuhi secara luas, nantinya dapat memberikan udara segar masuk ke dalam ruang-ruang yang ada di dalamnya. Hal ini dikarenakan udara segar yang masuk ke dalam telah tersaring dan membawa $\mathrm{O}_{2}$ yang dihasilkan dari proses fotosintesis tanaman vertikal. Selain aspek pencemaran udara yang diatur, vegetasi tanaman secara vertikal dapat dijadikan sebagai barrier kebisingan. Vegetasi ini nantinya dapat meredam dan membelokkan kebisingan dari berbagai arah bangunan terutama pada bagian depan yang mengarah langsung dan berdekatan dengan jalan utama.

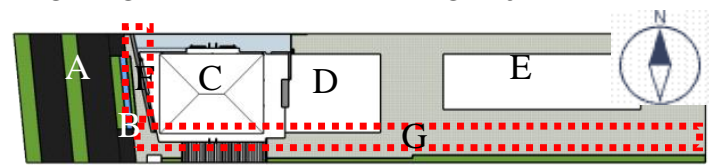

Keterangan:
A. Jln. Dr. Ir. Soekarno
B. Main entrance
C. Gedung baru kampus UKDC
D. Gedung lama kampus UKDC
E. Rusun mahasiswa
F. RTH eksisting bagian Barat
G. RTH eksisting bagian Selatan

Gambar 2. Site plan Kampus UKDC

Pada gambar 2 terlihat area letak RTH eksisting hanya berada di sisi Barat (lihat gambar 3) dan Selatan (lihat gambar 4). RTH Bagian Barat memiliki luasan eksisting $8 \mathrm{~m}^{2}$ dengan vegetasi berupa pohon papaya, cemara dan tanaman jenis perdu lainnya (lihat gambar 9).

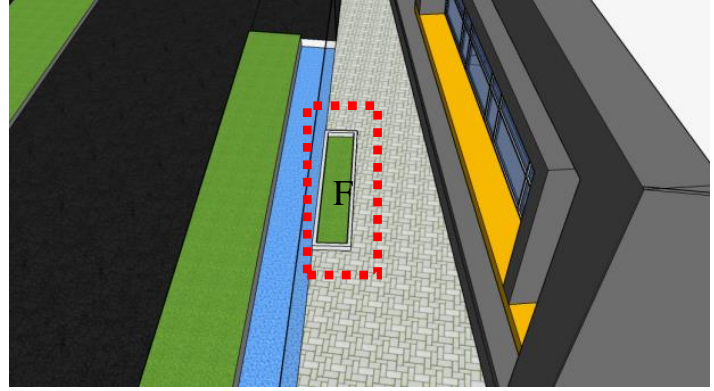

Gambar 3. Titik RTH bagian Barat

Sementara RTH bagian Selatan (lihat gambar 4) lebih memiliki luasan yang lebih lebar karena bentuknya yang memanjang dari Barat hingga ke Timur dan memiliki luasan $180,75 \mathrm{~m}^{2}$, sehingga kalau di total kedua RTH yang ada ini masih kurang dari 10\% (lihat gambar 9 dan 10).

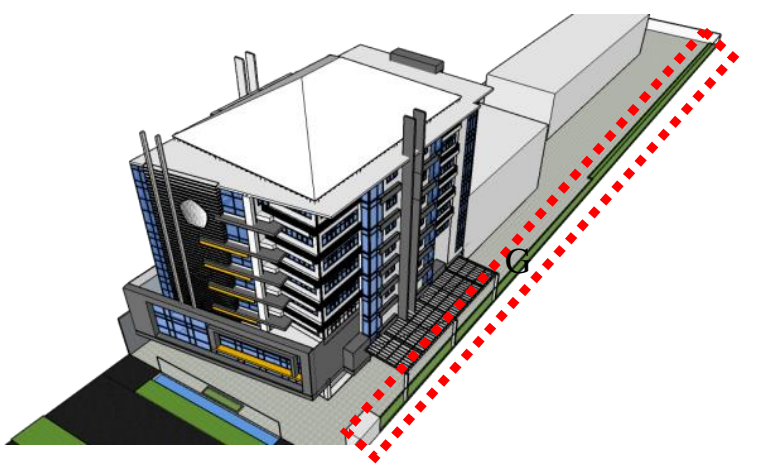

Gambar 4. Titik RTH bagian Selatan

Pada bagian Selatan bentuknya memanjang dari sisi Barat hingga ke Timur. Tidak adanya building envelope desain eksistingnya membuat bangunan ini selalu terpapar sinar radiasi matahari secara langsung di sepanjang jam. Massa bangunan sendiri masif dan dipenuhi dengan bukaan jendela kaca di berbagai sisi gedung. Bangunan dan lingkungan kampus UKDC secara eksisting masih terlihat gersang atau minim akan penghijauan sebagai area terbuka hijau. Kondisi gedung eksisting ini dapat terlihat pada gambar di bawah ini.

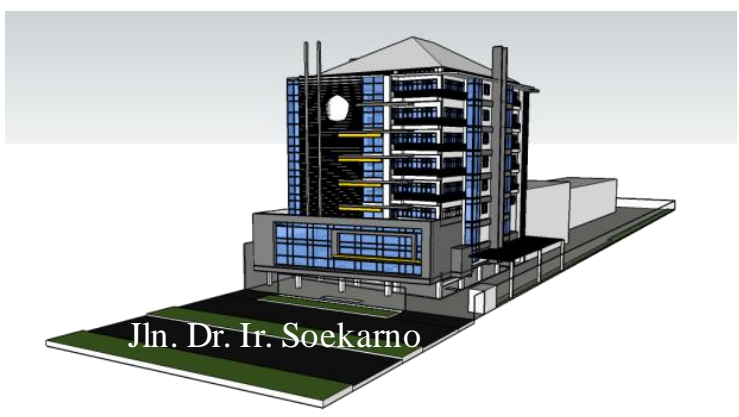

Gambar 5. Eksisting Gedung UKDC (View 1) Sumber:Hendra, 2020 


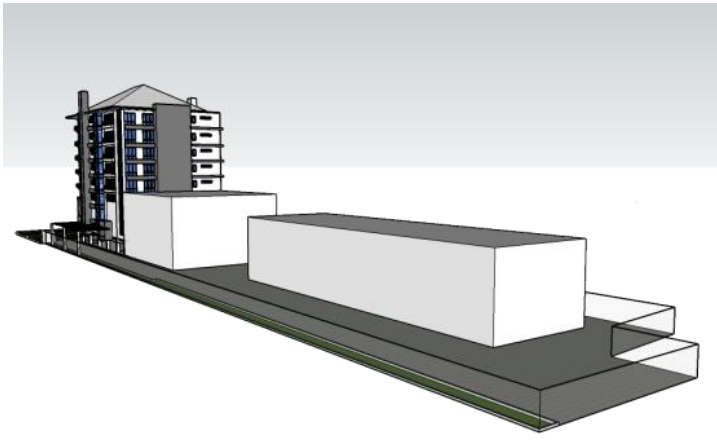

Gambar 6. Eksisting Gedung UKDC (View 2) Sumber:Hendra, 2020

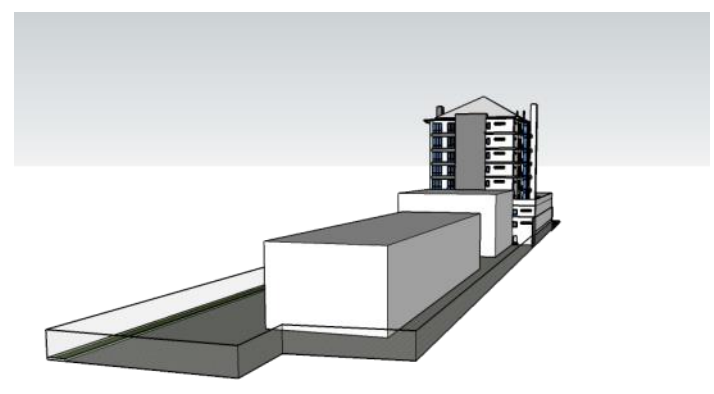

Gambar 7. Eksisting Gedung UKDC (View 3) Sumber:Hendra, 2020

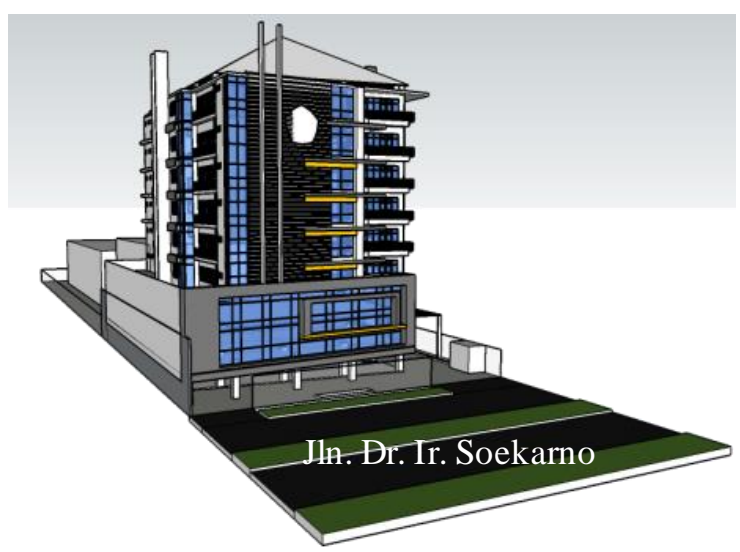

Gambar 8. Eksisting Gedung UKDC (View 4) Sumber:Hendra, 2020

Secara visual dan rasa yang dicapai pada kondisi sekarang (eksisting) ini bangunan menerima panas dari berbagai arah khususnya bagian Barat (lihat gambar 5). Pada bagian ini banyak sekali bukaan kaca secara langsung dan tanpa barier sehingga kondisi ini membuat ruang di dalamnya menjadi panas dan mengalami peningkatan suhu udara.

Dilihat dari jumlah RTH eksisting yang ada saat ini memiliki luasan total $180,75 \mathrm{~m}^{2}$ atau sekitar $2,61 \%$ sehingga dapat dikatan luasan RTH yang dimiliki oleh kampus UKDC pada lahan terbangun masih minim. Dengan rincian sebagai berikut:

Tabel 1. Rincian luasan lahan eksisting

\begin{tabular}{clcc}
\hline No. & Sisi & Luasan & Satuan \\
\hline 1. & Barat & 7,99 & $\mathrm{~m}^{2}$ \\
2. & Selatan & 172,76 & $\mathrm{~m}^{2}$ \\
& Total & 180,75 & $\mathrm{~m}^{2}$ \\
\hline
\end{tabular}

Selain itu guna pemenuhan penghijauan di lingkungan binaan diperlukan pembentukan dan menambah ketersediaan luasan RTH yang ada karena mengacu pada Perda Kota Surabaya No. 12 Tahun 2014 yang mengharuskan setiap lahan pribadi/swasta memiliki minimal $10 \%$ RTH. Mengacu gambar site plan (lihat gambar 2) beberapa area RTH eksisting yang ada di lingkungan kampus UKDC yang memiliki penghijauan yaitu sebagai berikut :

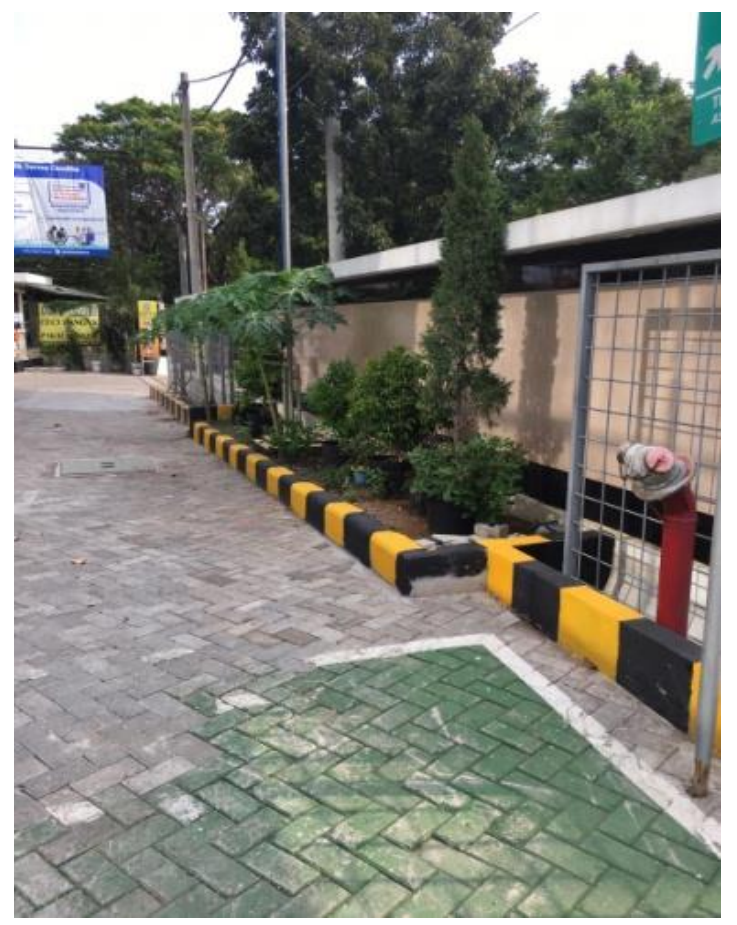

Gambar 9. RTH sisi Barat Gedung 


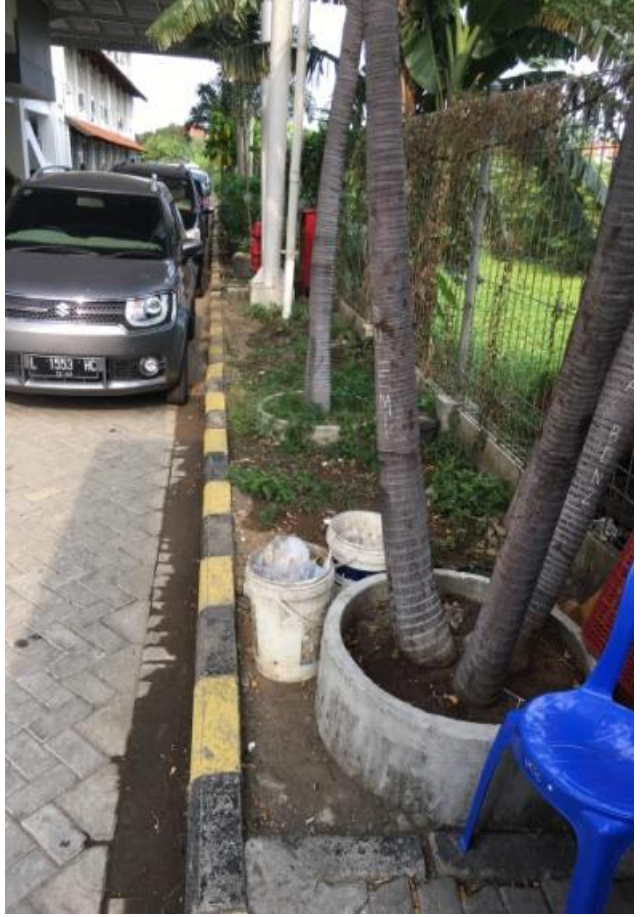

Gambar 10. RTH sisi Selatan Gedung

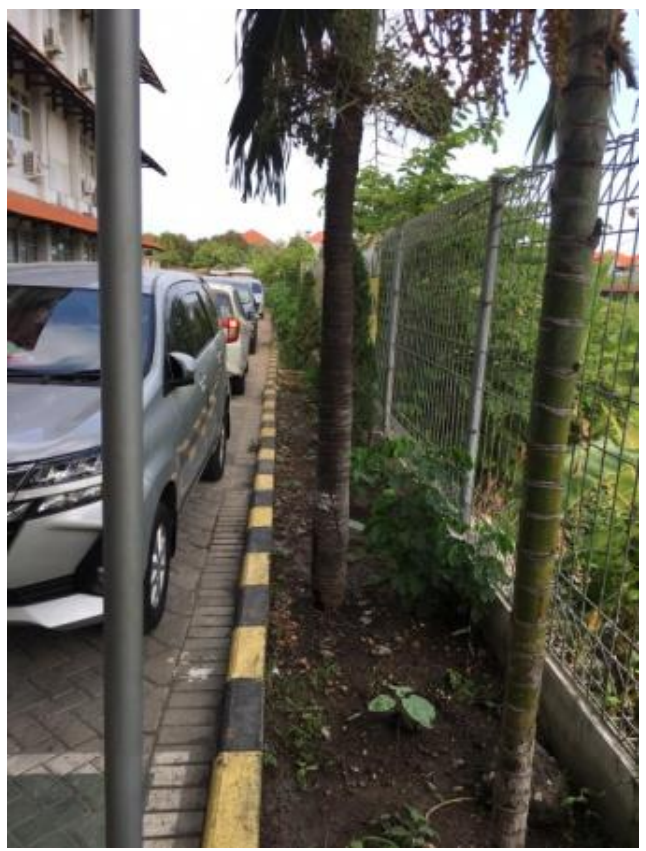

Gambar 11. RTH sisi Selatan Gedung

Terlihat dari gambar 9 hingga gambar 11, bahwa RTH yang bermedia tanah taman sebagai area resapan air masih terlihat minim. Banyak tanaman yang ada saat ini masih menggunakan media pot, sehingga tanah taman menjadi terbatas sebagai area resapan air, dan tanaman hanya berfungsi sebagai penambah elemen penghijauan saja. Ruang terbuka hijau haruslah benar-benar efektif dalam penempatan dan penggunaan serta keberadaannya untuk pengembangan suhu udara dan iklim sebuah kota supaya menjadi lebih baik dan nyaman (Rushayati, 2011).

Dilihat dari tabel 1. maka luasan RTH yang berada di kampus UKDC masih kurang sekitar $180,75 \mathrm{~m}^{2}$. Sehingga dilakukan penambahan vegetasi pada elemen gedung kampus sebagai medianya karena penambahan RTH secara horisontal sudah sangat tidak dimungkinkan. Hal ini dikarenakan lahan yang difungsikan untuk bangunan lebih besar hingga bagian belakang (sisi Timur) site.

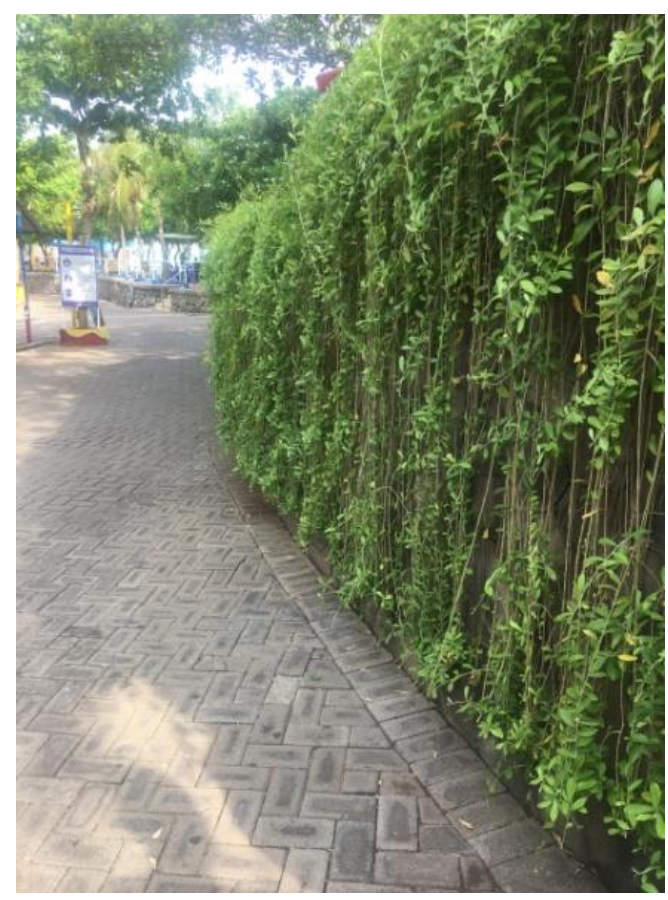

Gambar 12. Tanaman Vernonia Elliptica

Dengan menggunakan konsep vertical garden pada sebuah gedung bertingkat dengan kepemilikan lahan yang sempit atau minim mampu memberikan efisiensi lahan. Hal ini dikarenakan lahan yang diperlukan untuk ruang terbuka hijau dan area resapan air yang biasanya secara horisontal menjadi secara vertikal. Konsep secara vertikal ini sendiri dapat memberikan penambahan jumlah area media tanam. Maka dari itu secara perencanaan kedepan dari penelitian ini gedung kampus UKDC untuk menambahkan presentase RTH yang dimiliki digunakan konsep vertical garden agar memenuhi target minimal 10\% dari luasan lahan sesuai dengan Perda Kota Surabaya. Jadi secara keseluruhan jika dihitung 
secara luasan kampus UKDC diharuskan memiliki besaran minimal RTH yang tersedia sebesar $692,20 \mathrm{~m}^{2}$. Untuk memaksimalkan bidang dan penutup dari vegetasi yang ada diperlukan jenis tanaman yang masuk dalam kategori tanaman rambat. Tanaman yang dipilih pun yang mampu menyaring aliran angin panas, debu, dan sebagai barier dari panas serta suara, Vernonia Elliptica atau yang biasa dikenal dengan nama Lee Kuan Yew. Tanaman ini merupakan jenis tanaman rambat, umumnya lokasi penanamannya secara vertikal seperti pada area dinding dengan ciri-ciri menjulurkan batang-batang dan daunnya yang ringan. Karakteristik tanaman ini memiliki batang yang mampu menjalar sejauh 0.5 meter sampai 3 meter bahkan bisa lebih. Cara menanam tanaman ini dapat menggunakan tanah humus dan proses penyiramannya dapat dilakukan minimal satu kali dalam sehari. Ada beberapa jenis tanaman lain yang bisa dipilih sebagai alternatif dan pendamping vegetasi dari Vernonia Elliptica yang juga termasuk dalam tanaman rambat, diantaranya:
a. Morning of Glory (Ipomea)
b. Passiflora
c. Air Mata Pengantin (Antigonon)
d. Sirih Belanda (Scindapsus Aureus)

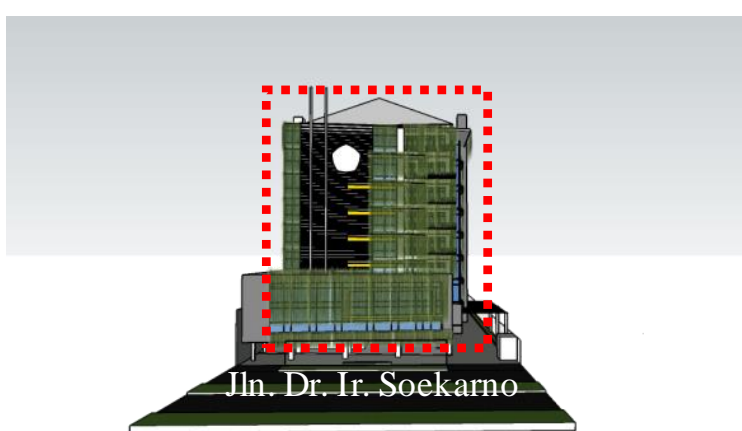

Gambar 13. Rencana RTH Gedung UKDC (Ba rat)

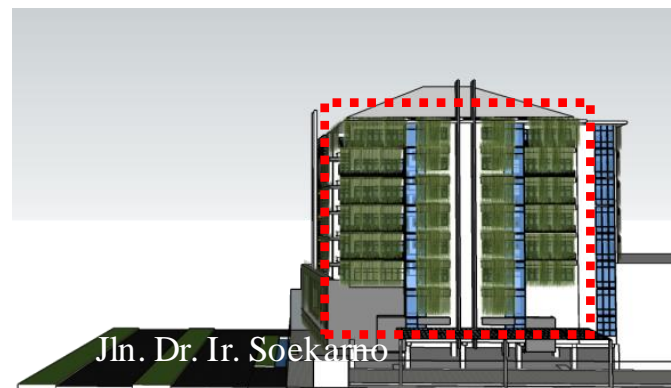

Gambar 14. Rencana RTHGedung UKDC (Selatan)

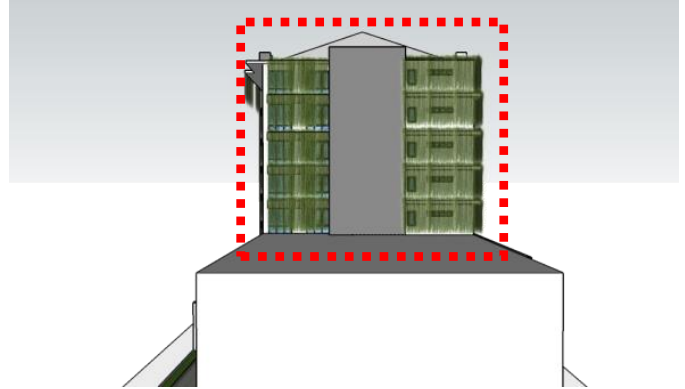

Gambar 15. Rencana RTH Gedung UKDC

(Timur)

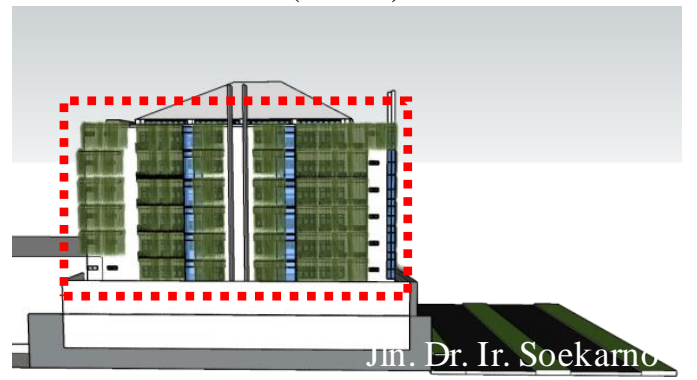

Gambar 16. Rencana RTH Gedung UKDC (Uta ra)

Arah hadap bangunan mengarah ke Barat dikarenakan lokasi atau site kampus UKDC yang langsung berhadapan dengan Jalan Dr. Ir. Soekarno (MERR) yang berada di sisi Barat. Sehingga main entrance dari gedung kampus UKDC ini juga menghadap ke sisi bagian Barat. Maka bentuk fasad bangunan yang paling terlihat dengan desain arsitektur juga berada di bidang bangunan sisi Barat yang dominan dengan bukaan kaca. Pembentukan RTH secara vertikal untuk gedung kampus UKDC terjadi hampir di sekeliling bangunan berlantai 9 ini. Luasan yang dicapai dari desain perancangan RTH yakni:

Tabel 2. Rincian luasan lahan rencana

\begin{tabular}{llcc}
\hline No. & \multicolumn{1}{c}{ Sisi } & Luasan & Satuan \\
\hline 1. & Barat & 693,50 & $\mathrm{~m}^{2}$ \\
2. & Selatan & 652,71 & $\mathrm{~m}^{2}$ \\
3. & Timur & 322,65 & $\mathrm{~m}^{2}$ \\
4. & Utara & 848,9 & $\mathrm{~m}^{2}$ \\
& Total & 2517,76 & $\mathrm{~m}^{2}$ \\
\hline
\end{tabular}

Luasan yang dicapai dari perencanaan penambahan vegetasi yaitu $2517,76 \mathrm{~m}^{2}$ atau $36,37 \%$, hal ini sesuai dengan Perda Kota Surabaya yang menyatakan bahwa tiap lahan gedung swasta wajib menghadirkan RTH minimal sebesar $10 \%$ dari luas lahan yang ada. Dari perhitungan desain perancangan $\mathrm{RTH}$ 
pada gedung kampus UKDC secara total didapatkan luasan $2698,51 \mathrm{~m}^{2}$. Luasan total ini didapatkan dari hasil penjumlahan RTH eksisiting dengan RTH perencanaan secara vertikal. Vertical garden sebagai alternatif yang paling efektif khususnya di daerah perkotaan dari permasalahan akibat semakin berkurangnya lahan penghijauan secara horisontal (Laloan, 2015).

Secara garis besar bidang paparan sinar matahari yang paling panas terjadi pada sisi gedung bagian Barat. Waktu paparan untuk sisi Barat sendiri terjadi antara pk. 13.00 hingga pk. 16.00, sehingga barier pada sisi ini harus dimaksimalkan dengan pembentukan RTH yang cukup. Bidang gedung UKDC yang menghadap ke Barat (lihat Gambar 13.) hampir keseluruhan tertutup dengan tanaman rambat Vernonia Elliptica khususnya bidang yang menggunakan material kaca. Tanaman ini nantinya berfungsi sebagai barier dari panas matahari Barat secara langsung sehingga radiasi dapat direduksi karena tanaman menyerap panas matahari dan terbentuk pembayangan di dalam ruang sehingga menyebabkan penurunan suhu pada area dalam gedung. Selain sebagai barier panas matahari, dapat berfungsi juga sebagai barier kebisingan yang diakibatkan lalu lintas kendaraan di depan gedung. Vertical garden untuk penggunaan lahan yang sempit dan minim dapat digolongkan sebagai area kawasan penyangga (Hastuti, 2008). Bisa dianggap sebagai area kawasan penyangga karena vertical garden yang difungsikan sebagai building envelope pada kampus UKDC dapat digolongkan sebagai ruang terbuka hijau pada suatu area atau lingkungan binaan sekitar.

Tanaman rambat ini secara perawatan dalam hal penyiraman menggunakan sistem utilitas pipa/selang terpusat yang langsung menyiramkan air ke media tanahnya. Jadi selang/pipa ditempatkan di sepanjang kanopi pada bangunan yang langsung berhadapan dengan tanah tanaman rambatnya.

\section{KESIMPULAN}

Secara garis besar pembentukan ruang terbuka hijau secara vertikal pada gedung kampus UKDC mampu memberikan nilai tambah terkait penerapan green building, mampu menyediakan RTH skala lingkungan dan penyediaan taman-taman skala kota. Selain itu mampu memberikan penambahan persentase penghijauan bagi skala kota. RTH secara vertikal mampu memberikan pelindung atau sebagai barier terhadap panas matahari, kebisingan, debu dan aliran udara panas yang menuju ke arah gedung kampus UKDC.

Secara luasan terkait peraturan daerah kota Surabaya dengan hasil penambahan tanaman secara vertikal didapatkan luasan total 2698,51 $\mathrm{m}^{2}$ atau didapatkan presentase sebesar 38,98\% untuk penambahan luasan RTH yang diwajibkan guna dihadirkan dalam sebuah site. Sehingga ada penambahan $36,37 \%$ dari persentase luasan eksisting RTH. Dengan hasil luasan yang diperoleh maka syarat minimal untuk ketersediaan dan pemanfaatan RTH telah tercapai bahkan lebih.

Tabel 3. Total lua san RTH yang tersedia

\begin{tabular}{clcc}
\hline No. & Status Lahan & Luas & Prosentase \\
\hline 1 & RTH & $180,75 \mathrm{~m}^{2}$ & $2,61 \%$ \\
& eksisting & & \\
2 & RTH rencana & $2517,76 \mathrm{~m}^{2}$ & $36,37 \%$ \\
& Total & $2698,51 \mathrm{~m}^{2}$ & $38,98 \%$ \\
\hline
\end{tabular}

Konsep vertical garden dipilih untuk memaksimalkan area lahan yang dapat difungsikan secara efektif dan guna sebagai building envelope untuk gedung kampus UKDC. Untuk itu penambahan RTH dibuat secara vertikal, hal ini dilakukan karena lahan kosong yang ada saat ini dalam site sudah sangat minim sehingga penggunaan secara horisontal untuk RTH dan area resapan sudah sangat tidak memungkinkan. 


\section{UCAPAN TERIMAKASIH}

Penelitian ini dilakukan dengan kerjasama antara dosen Arsitektur dengan pihak Universitas beserta Konsultan Perencana yang telah mendesain gedung baru kampus UKDC. Pihak prodi Arsitektur yang juga memberikan support hingga penelitian ini dapat terselesaikan.

\section{REFERENSI}

Afrizal E. I., Fatimah I.S., Sulistyantara B. (2010). Studi Potensi Produksi Oksigen Hutan Kota Di Kampus Universitas Indonesia, Depok. Jurnal Lanskap Indonesia. Vol. 2 No. 1. Hal.

Ahmad, F., Arifin, H.S., dkk. (2012). Analisis Hubungan Luas Ruang Terbuka Hijau (RTH) dan Perubahan Suhu di Kota Palu. Jurnal Hujan Tropis, Vol. 13 No. 2. September 2012.

Akbari H. (2008). Saving energy and improving air quality in urban beat islands. Berkeley: American Institute of Physics.

Arifin, H. S. A dan Nurhayati. (2000). Pemeliharaan Taman. Penebar Swadaya. Jakarta.

Arikunto, Suharsimi. (2006). Prosedur Penelitian. Jakarta: PT. Rineka Cipta.

Caesarina H., Saubari N. 2019. Peran Ruang Terbuka Hijau Dalam Perencanaan Kota Sebagai Potensi Pembentuk Smart City. Jukung Jurnal Teknik Lingkungan. Vol. 5 No. 1. Hal. 28-39.

Chafid Fandeli, Kaharuddin dan Muklison. 2004. Perhutanan Kota. Yogyakarta: Fak. Kehutanan UGM.

Daylight and Productivity: A Field Study. (http://eec.ucdavis.edu/ACEEE/2002/pdfs/ panel08/06_15.pdf)

Dewiyanti D. 2009. Ruang terbuka hijau kota bandung (suatu tinjauan awal taman kota terhadap konsep kota layak anak). Majalah Ilmiah UNIKOM, 7 (1): 13-26.

Direktorat Jenderal Penataan Ruang. Departemen Pekerjaan Umum. Pedoman Penyediaan dan Pemanfaatan Ruang Terbuka Hijau di Kawasan Perkotaan, Pedoman Penyediaan dan Pemanfaatan Ruang Terbuka Hijau di Kawasan Perkotaan. 2008.
Dwiyanto, A. 2009. Kuantitas dan Kualitas Ruang Terbuka Hijau di Permukiman Perkotaan. Teknik, Vol. 30 No. 2.

Hastuti E., Utami T. 2008. Potensi Ruang Terbuka Hijau Dalam Penyerapan $\mathrm{CO}_{2}$ di Permukiman. Jurnal Permukiman, Vol. 3 No. 2. Hal. 106-114

Jormakka, K. (2007). Basics Design Methods. Berlin: Birkhauser.

Kusmana, C. 2015. Keanekaragaman Hayati (Biodiversitas) Sebagai Elemen Kunci Ekosistem Kota Hijau. Jurnal Pros Sem Nas Masy Biodiv Indon. Vol. 1 No.8. Hal. 1747-1755.

Kusumawardani, D. (2017). Arahan Penyediaan Ruang Terbuka Hijau dalam Menyerap Emisi Gas CO2 Kendaraan Bermotor pada Kawasan Industri Sier, Surabaya. Jurnal Teknik Sipil dan Perencanaan.

Laloan, Y., Prijadi, R., Moniaga, I. 2015. Apartemen di Manado Penerapan Konsep Vertical Garden. Jurnal Arsitektur Daseng, Vol. 4 No. 2. Hal. 10-18.

Nugradi, D., 2009. Identifikasi Ruang Terbuka Hijau Kota Semarang. Jurnal Teknik Sipil dan Perencanaan. Vol. 11 No. 1. Hal. 6170.

Panduan Pengguna Bangunan Gedung Hijau Jakarta. Berdasarkan Peraturan Gubernur No. 38/2012. Vol. 3. Sistem Pencahayaan

Peraturan Daerah Kota Surabaya No. 7 Tahun 2002, tentang Pengelolaan Ruang Terbuka Hijau

Peraturan Daerah Kota Surabaya No. 12 Tahun 2014, tentang Rencana Tata Ruang Wilayah Kota Surabaya Tahun 2014-2034

Peraturan Daerah Kota Surabaya No. 15 Tahun 2014, tentang Hutan Kota

Prabowoningsih, N., Putri, R., Rini, E. 2018. Faktor-Faktor Yang Mempengaruhi Ketersediaan Ruang Terbuka Hijau Pada Setiap Dominasi Penggunaan Lahan (Studi Kasus: Kota Surakarta). Region: Jurnal Pembangunan Wilayah dan Perencanaan Partisipatif. Vol. 13 No. 2. Hal. 133-151.

Putri, D, Soemardiono, B, Suprihardjo, R,. 2017. Konsep Penataan Ruang Terbuka Hijau di Kawasan Pusat Kota Ponorogo. Jurnal Penataan Ruang. Vol. 7 No. 1.

Rushayati, SB., Alikodra, HS., (2011). Pengembangan Ruang Terbuka Hijau 
Berdasarkan Distribusi Suhu Permukaan di Kabupaten Bandung. Forum Geografi, Vol. 25 No. 1. Juli 2011.

Samsudi. 2010. Ruang Terbuka Hijau Kebutuhan Tata Ruang Perkotaan Kota Surakarta. Journal of Rural and Development, Vol. 1 No 1. Februari 2010. Setyani, W. 2017. Analisis Ruang Terbuka Hijau dan Kecukupannya di Kota Depok. Buletin Tanah dan Lahan, Vol. 1 No. 1. Hal. 121-127.

Suciyani, W. O. 2018. Analisis Potensi Pemanfaatan Ruang Terbuka Hijau (RTH) Kampus Di Politeknik Negeri Bandung. Jurnal Planologi, Vol. 15 No. 1. Hal. 17-33. 